\title{
Glancing at Trend and Challenges of Fire Safety in Indonesia
}

\author{
Suprapto \\ The Indonesian Fire Protection Association, Indonesia
}

Good afternoon ladies and gentlemen. My name is Suprapto. I am representing my organization. It's called Indonesian Fire Protection Association. (Figure 2-5-1) But since I have been working for long time in Research Institute for Human Settlement Ministry of Public Work where in 1990 there was a cooperation with Ministry of Construction, Japan. Then also my paper will be colored by some experience dealing with the fire research and education.

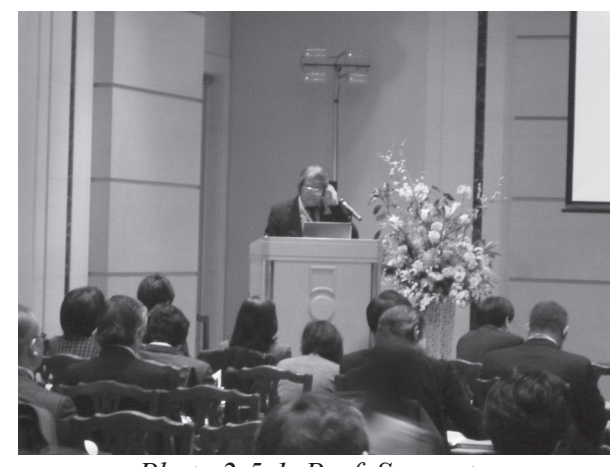

Photo 2-5-1 Prof. Suprapto

This is Indonesia, so 17504 islands, 33 provinces, 300 sub-provinces and 98 municipality. (Figure 2-5-2) So it's quite many and some area trying to develop to what we call, to try them to make something new.

So since quite a large of the provincial government or sub-provincial government actually is not quite good. But this is the fact.

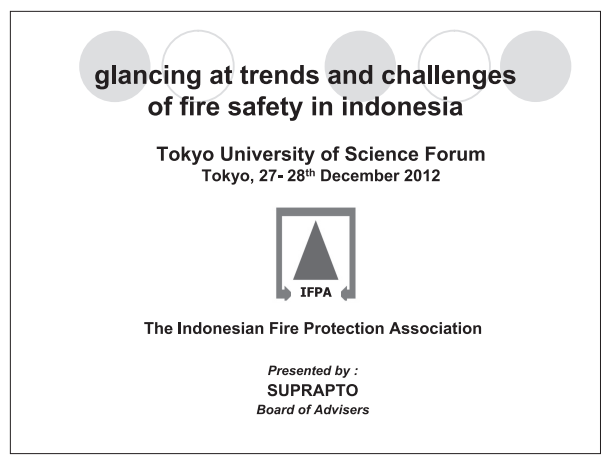

Figure 2-5-1

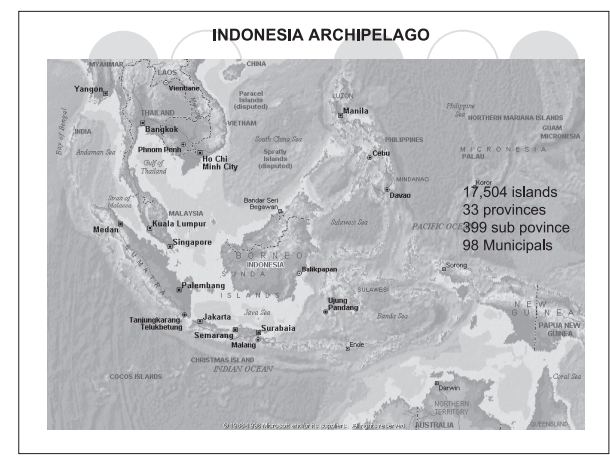

Figure 2-5-2

We are archipelago and this is Indonesia among Asia countries, so we have - we see Japan, we see Thailand, we see Malaysia and so on. (Figure 2-5-3)

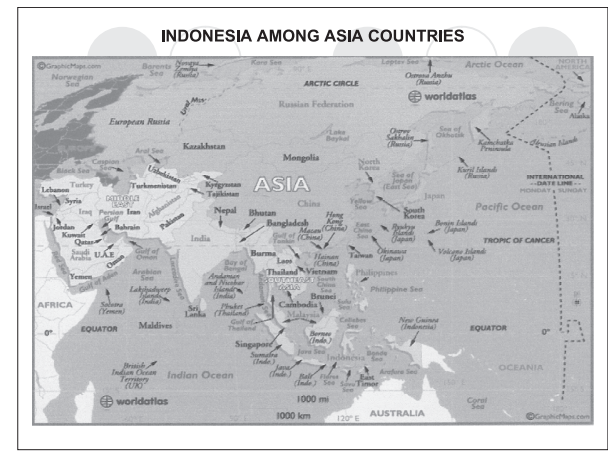

Figure 2-5-3 
The thing that I would like to talk is about introduction fire incident data. (Figure 2-5-4) Seen from the data we can set up the policy, whatsoever and regulation. So based on the data. So I was long time appreciate what Dr. Sekizawa did about the fire statistic in Japan, but it's quite difficult to set up the fire statistic in Indonesia. When somebody asked what is the number of fire in Indonesia we cannot answer directly because the data is kept in every municipality and data is not actually uniform.

\section{Subjets to talks}

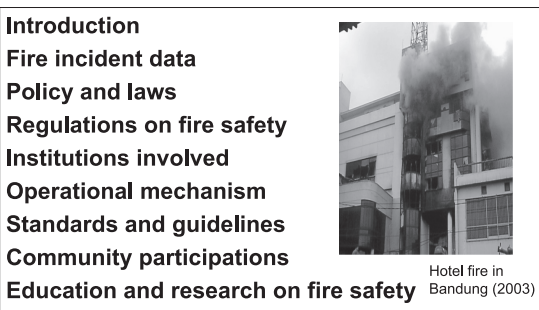

Figure 2-5-4

In 2005 we had idea to make uniform fire report system, but until now it hasn't worked. We will talk about policy and laws, regulation, institution involved, operational mechanism, standards and guideline, community participation, and education and research on fire safety. This is something that I would like to talk. My presentation is somewhat general but at least give the picture what we are doing there. We have also challenges, we have also some trend also.

There are various type of fire in Indonesia. (Figure 2-5-5) We have building fires, industrial fires, forest fire, pit fires, pit fire is what we call a pit, there is something which is 3 meters below the ground in Kalimantan in which whenever the fire occur in that pit, then people can directly absorb in the ground. So this is quite typical.

Oil and gas arson fires. Like in Bali there

\section{INTRODUCTION}

- There are various types of fires in Indonesia, such as building / residential fires, industrial fires, forest fires, peat fires, oil and gases fires, and arson fires. Some others like transportation means fires, mining fires are limited in number and information. Due to many types of fires, severa related institutions has specific program to overcome these problems such as Ministry of Public Works (MPW), Min. of Forestry, Ministry of Mining \& Energy. Currently, some local governments guided by MPW has set- up of fire safety master planning to make effective and efficient control of urban fires, particularly by determinining or placing more fire command posts and increasing the weight of attacks.

Figure 2-5-5

is also arson fire, we have also terrorism and so we are trying to reduce it. Some other like transportation means fires mining are limited in number and information. Due to many types of fires, say for instance, the institution has specific program to overcome this problem such as Ministry of Public Work where I am working. Ministry of Forestry, Ministry of Mining and Energy. Currently some local government guided by Ministry of Public work has set up fire safety Master Planning just to set up the what number of fire posts. So that respond time and weight of attack from the fire brigade can be sufficient. 
This is the type of fires. (Figure 2-5-6) We have building fire, under Ministry of Public Works. Then field operator is municipal fire brigade. Hydrocarbon fire like oil and gas, including storage fire is under Ministry of Mining and Energy. So regulator means they create a guidance, they create also a standard, standard for oil and gas from API usually American Petroleum Institute. While for [Unclear] we use from NFPA, sometime also from GIS because our laboratory is referred TYPES OF FIRE \& AUTHORIZED INSTITUTIONS

\begin{tabular}{|c|l|l|l|}
\hline No & \multicolumn{1}{|c|}{ Type of fires } & \multicolumn{1}{|c|}{ Regulator } & \multicolumn{1}{|c|}{ Field Operator } \\
\hline 1 & Building fires & $\begin{array}{l}\text { Ministry of Public } \\
\text { Works }\end{array}$ & $\begin{array}{l}\text { Municipal Fire Brigade } \\
\text { (MFS) }\end{array}$ \\
\hline 2 & $\begin{array}{l}\text { Hydrocarbon (oil \& } \\
\text { gas fires) incl oil } \\
\text { storage fires }\end{array}$ & $\begin{array}{l}\text { Ministry of Mining \& } \\
\text { Energy }\end{array}$ & $\begin{array}{l}\text { Oil \& Gas State-owned } \\
\text { company } \\
\text { (PERTAMINA) }\end{array}$ \\
\hline 3 & Forest fire & Ministry of Forestry & $\begin{array}{l}\text { MANGGALA AGNI } \\
\text { Forest Fire Brigade }\end{array}$ \\
\hline 4 & Peat fires & $\begin{array}{l}\text { Ministry of } \\
\text { Agriculture }\end{array}$ & $\begin{array}{l}\text { Community fire brigade } \\
\text { (volunteer) }\end{array}$ \\
\hline 5 & Train fires & $\begin{array}{l}\text { Ministry of } \\
\text { Transport }\end{array}$ & $\begin{array}{l}\text { Indonesia Train } \\
\text { Company (KAI) }\end{array}$ \\
\hline 6 & Fires in work place & Ministry of Labour & $\begin{array}{l}\text { Internal fire emergency } \\
\text { response team, MFS }\end{array}$ \\
\hline
\end{tabular}

Figure 2-5-6 to GIS and sometime also BSN so.

Field operator for hydrocarbon is oil and gas state owned company, Pertamina. Forest Fire, Ministry of Public, forestry, they have also special brigade for forest fire called Manggala Agni. Pit fire, Ministry of Agriculture and usually they are done by community fire brigade because fire brigade cannot do anything because pit fire can happen any times. So they have volunteers coming from the grassroots, they setup their own fire brigade. Train fires, Ministry of Transport and the operator is Indonesian Train Company and fire in work place, Ministry of Labor, internal emergency response team, this is what we call Occupational Safety.

Fire incident data that we can propose, we can forward to you is two cases in Surabaya and Jakarta and this is studied by two gentlemen from University of New South Wales Sufianto from Indonesia and Mr. Green and they thought that Surabaya and Jakarta have frequent fire incidents. (Figure 2-5-7) In the last 7 years, 2002, 2008 the average 321 and Jakarta is 445 every year.

Roughly Jakarta is the most number of fire; 3 times fire a day and then followed by the other. (Figure 2-5-8) We have typical fire what is kampung fire, kampung is where people stay in very substandard. We have also what we call ruko. Ruko is mix between housing and mercantile where they put bar for protecting themselves against theft. But coincidentally sometimes they become trap

\section{FIRE INCIDENT DATA (2 CITIES)}

This data is available in each municipal
government, in this case local fire brigade.
Therefore, fire data for the whole Indone-
sia area is still unquantified. Anyone
interested in fire incident data may select
to the city concerned such as Jakarta,
Bandung etc. Fire incident data in Jakarta
and Surabaya, as reported by H.Sufianto
$\&$ A.R Green $<1>$ showed that Surabaya
and Jakarta have frequent fire incidents.
In the last 7 years ( $2002-2008$ ), Surabaya
has an average of 321 fires and Jakarta
exceeds 840 fires every year (Table-1).

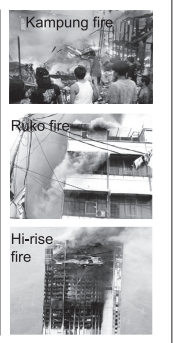

Figure 2-5-7

\section{FIRE INCIDENT DATA (continued)}

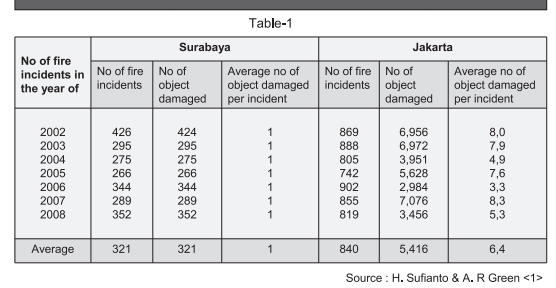

Efforts to set-up mechanism for unifying fire report system, have been actually conducted in 2007-2008 by the Directorate of Disaster Mitigation of the Ministry of Home Affair, but was not continued since then. 
whenever there is a fire and we have also fire in the high-rise building. That's very interesting because they use what we call buck pail of water because according to some gentleman from Malaysia that a fire actually can be extinguished enough by one bucket of pail as long as in the right time. This is not in the right time because this is already big fire.

This is my incident data that we can propose to you that about 800 Jakarta and about 500 Surabaya. (Figure 2-5-9) Mostly the cause of the fire is because of oil stove. This one is oil stove; it is the higher. Oil stove and electricity and cigarette and others. Others include rubbish fire or welding fire, firework and many others. Oil stove has become the number one because of carelessness and because of the sometimes they do not care about they do not

FIRE INCIDENT DATA (continued)

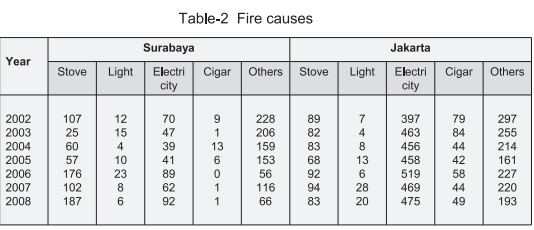

Source : H. Sufianto \& A. R Green <1>

The other causes consist of bun-off grass, rubbish fires, welding torch fires, fireworks, children playing with matches, in-appropriate vehicle fuel filling 政

Figure 2-5-9 learn about how to make this equipment safe. But now because of the conversion to gas, LPG, LNG it is also creating another problem because they always explode.

The incident data in Indonesia - I am sorry to say that - is not settled up yet. (Figure 2-5-10) Fire data recorded by a fire brigade, merely number of fire accident, time of fire accident, cause of fire, number of casualties, number of fire product was released, duration of fire and estimated losses, coverage area burned. This is usually recorded by fire surface data in every municipal.

They do not have what we call death per million, how many people die per million cases, no. (Figure 2-5-11) This is something that we try to complete that so we can have a correspondent with the other country. This is also another thing that the number of death or injury per incident.

\section{FIRE INCIDENT DATA (continued)}

Fire data recorded by Fire
Brigade / MFS are :
$\square$ Number of fire incident
$\square$ Time of fire incident
$\square$ Cause of fire
$\square$ Number of casualties
$\square$ Number of fire apparatus
released
$\square$ Duration of fire
$\square$ Estimated losses
$\square$ Coverage area burned

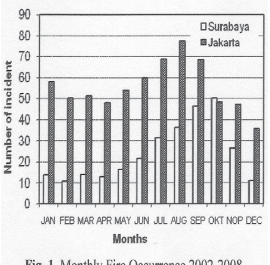

Figure 2-5-10

\section{FIRE INCIDENT DATA (continued)}

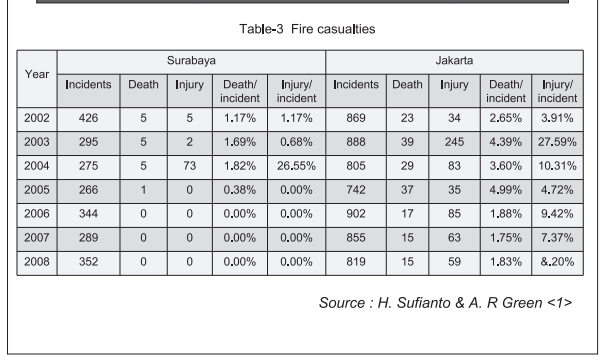

Figure 2-5-11 
The potential fire risk in Indonesia. (Figure 2-5-12) This is because of domestic oil stove change by the program of government to use LPG. People sometimes very shocked because they do not know that it is very flammable gases and sometimes they face a very big explosion and because of the character of building that is close to each other, then it becomes conflagration. Same like this, that pictures this all the people,

\section{POTENTIAL FIRE RISKS IN INDONESIA}

- Domestic oil stove changed to use gas fuel (LPG)

- High-voltage electricity (220 V)

- Increased hi-rise building without suffficient protection

- Underground structures

- Slums areas are extending in urban areas causing big fires (conflagration)

- Natural disasters \& calamity

- Security problem \& terrorism

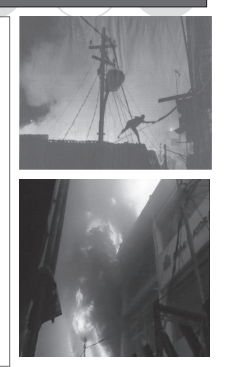

Figure 2-5-12 here is trying to draw the pipe, the hydrant from the fire brigade. Because they do not want to make their house burn.

Then in Indonesia we have what we call high voltage electricity, 220 voltage, so it's quite critical actually. In the 1970 s, it is 110,100 , so we can touch it easily but now because to cover the whole number of people then we try to sacrifice with the high electricity.

In case of high rise building with a sufficient protection and ground structure, slums area are standing in urban areas causing big fires, conflagration, sometimes more than 200 fires in Palembang in South Sumatra, 1500 houses burn. Then natural disaster and calamity and security problem and terrorism, this is one thing that create risk of fire.

We try to use this approach. How about the policy of fire? (Figure 2-5-13) How about the legal devices as the derivation of policy, how about the institutions involved, how about the operational mechanism and how about the standard. When this is already complete then I am sure fire can be minimized, but in fact there are so many things that we admit it should be improved.

Policy on fire. (Figure 2-5-14) There is no

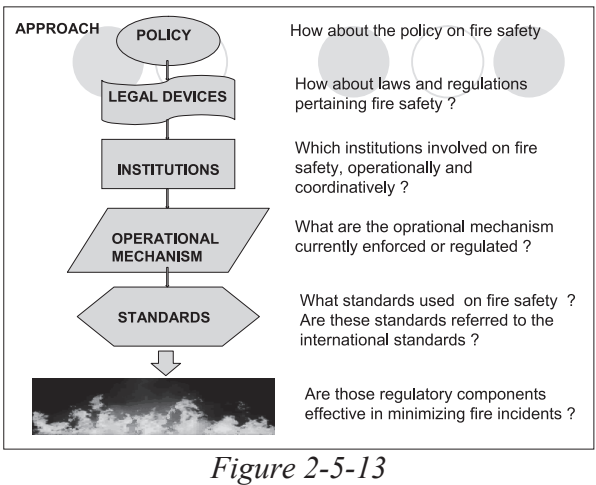
specific policy on fire actually. But it is possibly included in the other aspect of national defense policy. For example, there is the obligation of the state to protect each citizen against fire and disaster. The state keeps safety and welfare of the citizen unexceptionally to ensure the protection against fire threat of fire through the issuance of laws and regulation. Theoretically yes, like this but we have four champion of

\section{POLICY ON FIRE SAFETY}

Although, there is no specific policy on fire safety, since it is possibly included in other aspects of national defence policy, however, it is the obligation of the state to protect each citizen against fire and disaster.

The state keep save and welfare of the citizen unexceptionally to ensure the protection against the threat of fire through the issuance of laws and their enforcement, setting-up codes and standards, promoting research and education.

Figure 2-5-14 
chess in Batang because they live in poor condition, dead because of fire, so it is not in confirmation with this policy.

The policy should be derived with the laws. (Figure 2-5-15) We have laws, Occupational Safety, Law Number 1. Disaster Mitigation Law 24. Spatial Law in which how to set up space for building and in this space also we regulate what we call fire protection, fire command posts based on this law. What we call fire management area, yeah, Environment Protection Law and Building Law which is quite popular now because from

\section{LAWS PERTAINING FIRE SAFETY}

- Occupational Safety Law no 1, year1970,

- Disaster Mitigation Law no 24/2007

- Spatial Law no 26/2007,

- Environment Protection Law no 32/1009

- Building Law no 28/2002. Under the heading of safety aspects (other aspects are health, comfort and accessibility), fire safety is a compulsary to be provided in any building and its environs beside safety against earthquake and lightning.

- Problem related to safety law : No fire service law has been specifically formulated yet

Figure 2-5-15 this law and then following with the Ministry Ordinance called Permen and this Permen will be used a guidance for municipality to make their own fire code. See here that there is no fire service law. You have in Japan, you have fire service law but we do not have fire service law. Perhaps, this is one thing that we can also propose.

Then national regulation on fire safety protection. (Figure 2-5-16) Regulation on fire safety which are derived from this above law are then formulated in the form of ministerial regulation or Permen. To bring this regulation into operation in respective cities by local government ordinance or regulation in the form of local fire brigade, local fire code shall be formulated. So Permen is a model, as a reference for each municipal to make their own law based on the resource available.

Ministerial a regulation that we have already issued Number 29, technical requirements for building and then building permit, building reliability certificate. (Figure 2-5-17) This following with what we call certificate of feasible reliability in which if the building is changed for example, from restaurant to become entertainment or assembly they have to have such specific certificate because the load will be different. The load will be changed.

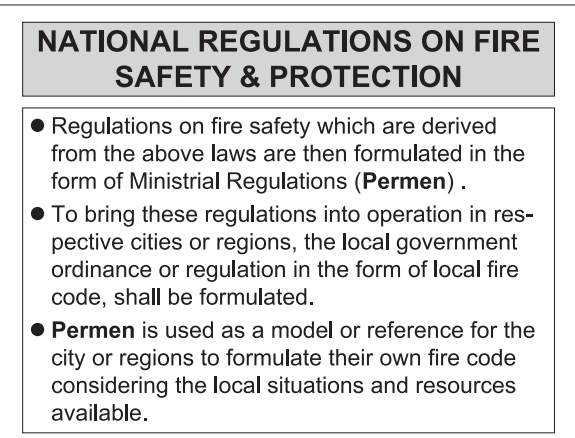

Figure 2-5-16
MINISTRIAL REGULATIONS (PERMEN)

- Permen no 29/2006 : Technical requirements for buildings

- Permen no 24/2007 : Building Permit Requirements

- Permen no 25/2007 : Building reliablity certificate

- Permen no 25/2008 : Fire safety management in urban areas (incl. building- area-city)

- Permen no 26/2008 : Fire protection requirements for buildings and its environs

- Permen no 20/2009 : Guidance to set-up fire master planning in a city

- Permen no 16/2010 : A Guide of building fire inspection 
Fire safety management in urban areas, fire protection requirement for building and it's environ, guidance to set up master planning in a city, it is for fire brigade. A guide of building fire inspection. Response time Indonesia is much more than 10 minutes. We have agreed 15 minutes but here in Tokyo response time is 8.5 minutes or less than 10 minutes. So this is something that we are trying to achieve this.

Cities with local fire code is only big cities whereas the other cities they do not have fire code. (Figure 2-5-18) It is quite difficult for authority having jurisdiction to make some inspection, to give some permit answer. Usually we are basically prescriptive in nature. We do not apply what we call performance based method. So this is a problem, because consultant, some of them use performance based but authority having jurisdiction cannot give, just cannot become a

\section{CITIES WITH LOCAL FIRE CODE}

- Local fire code have been drafted and formulated by the city of Jakarta, Bandung, Surabaya, Semarang, and Makasar which refer to national regulations (Permens), code and standards. Most reguations used in Indonesia are basically prescriptive in nature. The use of performancebased method is still limited to specific study and research.

- Problems : Not all city or area have fire code (approximately $26 \%$ of the total cities, by 2011)

Figure 2-5-18 judge to say this yes or no because they do not have any idea, they haven't any knowledge about performance based. Problem is that not all city or area have fire code. Approximately $26 \%$ of the total cities. So, it is obligation for the government to make some socialization.

Now, institutions that are involved in fire. Perhaps the same with other country. (Figure 2-5-19) Municipal fire brigade, municipal fire services and several also involved before and during and after. So we set up what we call SOP, standard operating procedures, what institution involved and what they do, before, during and after fire incident.

\section{INSTITUTIONS INVOLVED IN FIRE}

- The institution responsible in fire incident comand systems of fire fighting, and rescuing people is the Municipal Fire Services or Fire Brigade (MFS/MFB)

- Several institutions which are involved, before , during and after fire incidents are the regional offices of the ministrial of transport, public works, man-power, social, education, police department, local government, water supply department, electricity state-owned enter-prise, neighbor-hood community and local communities.

Figure 2-5-19

Some problem, not all cities have master planning program; only 8\%. (Figure 2-5-20)

Because with this program which is going on to set up, we put the special post-fire recommend post in such a way, so that the number of fire command posts can ensure the time respond of the fire brigade and also the weight of attack of the fire brigade almost.

\section{MUNICIPAL FIRE SERVICES (MFS)}

- Some problems : Not all city of region have master planning program (only $8 \%$ ), besides the commitment of city head are still low in overcoming or minimizing fire incidents. Furthermore, many MFS are facing problems of man-power, equipment and completing fire apparatus.

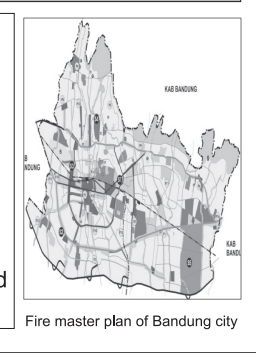

Figure 2-5-20 
Now, role of fire service. (Figure 2-5-21) Basically the task of municipal fire service include prevention, control, and suppression hazardous material response and community participation. Based on the Law Number 24 concerning disaster mitigation, the role of municipal fire service is extended to include rescuing people during disaster strike.

Role of fire service continued. (Figure 2-5-22) Based on Permen 25 the municipal fire service takes part in evaluating fire safety performance of building before the issuance of functional reliability certificate, which is now going to be applied.

Then operational mechanism is now just derivation number 4 is operational mechanism. (Figure 2-5-23) How the operating procedure, SOP, master planning can be applied in every city? Currently the government recommend the city management to draft SOP on institutional coordination and master planning in order to increase performance of municipal fire service in combating the fires. But, problem related to operational mechanism; not all city has commitment to draft SOP or setting up fire master planning and need some effort to socialize this matter.

Standard and guidelines. (Figure 2-5-24) Now, we have about 32 standard SNI, Standar Nasional Indonesia on fire safety has been formulated. Basically it's referred to NFPA standard. Standard are drafted by involving several related government institution, research institution, university, professional association, universities, representative from consultant association, developers, and National Standard Body. So those are

\section{Role of Fire Services (MFS)}

Basically the tasks of MFS include fire prevention, fire control and suppressison, hazardous material responses, and community participation

- Based on the Law no 24/2007 concerning disaster mitigation, the role of MFS is extended to include rescuing people during disaster strike.

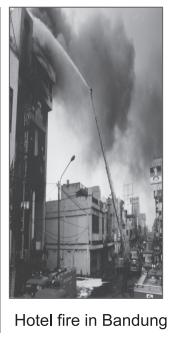

Figure 2-5-21

\section{Role of Fire Services (continued)}

- Based on Permen no 25/PRT/M/2007, the MFS takes part in evaluating fire safety performance of buildings before the issuance of SLF (functional reliability certificate) by the Local Government.

- No fire service law, except the law no 24/2007 concerning disaster mitigation which is used as a reference in operational measures (preparedness - early detection mitigation).

Figure 2-5-22

\section{OPERATIONAL MECHANISM (OM)}

- OM includes standards operating procedures (SOPs), master planning (RISPK), operational guidelines etc.

- Currently, the government recommends the city management to draft SOP on institutional coordination and RISPK in order to increase performance of MFS in combatting fires.

- Problem related to operational mechanism : Not all city or region has a commitment to draft SOP or setting-up RISPK (fire master planning). Need some efforts to socialize these matters.

Figure 2-5-23

STANDARD \& TECHNICAL GUIDELINES

- There are currently about 32 standards $\mathrm{SNI}$ on fire safety have been formulated. Standards are drafted by involving several related government institutions, research institutions, universities, professional associations, universities, representatives form consultants association, developers, insurance industry, and National Standard Body (BSN).

- All standards to be drafted shall referred to the International standards such as ASTM, NFPA, JIS, AS, BS etc. The 32 standards are attached.

Figure 2-5-24 
involved in setting up, in preparing the academic - what we call - manuscript for standard and then verified by BSN. All standard to be drafted shall be referred to the international standards, so it is a must ASTM, NFPA, JIS, AS, BS, etcetera.

Problems with standard. (Figure 2-5-25) Since there is only one technical committee admitted for fire safety according to BSN hence standard or SNI productivity including revision, abolishing, and drafting becomes slower. We have standard but addition in the year of 2000 is already 2012. So I think so many are enthusiastic in drafting a standard. That is the problem.

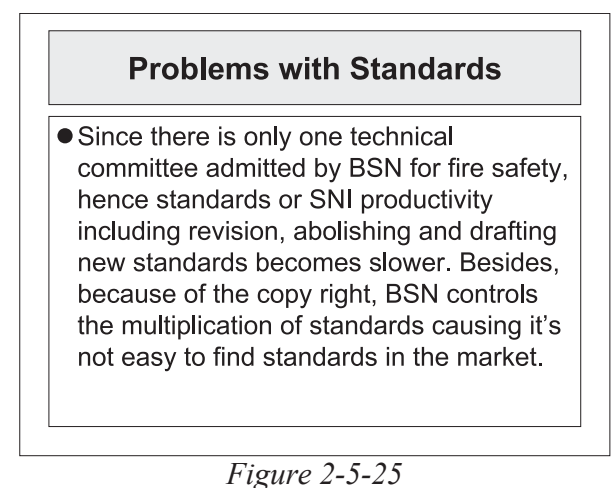

Beside because of the copyright BSN controls the multiplication of standard causing it's not easy to find standard in the market because they have what we call a copyright. That is, they should have some permission from BSN before copying the standard. So standard becomes quite difficult to be find in the book store and so.

Now, partnership in professional association. (Figure 2-5-26), (Figure 2-5-27) We have partnership with professional association in trying to help government in solving the problem and trying to make some database and so. Some numbers of professional association are Indonesian Fire Protection Association in which I belong where Mr. Ganis Ramadhani - Professor Kobayashi knows him - and APKI, the Association of Indonesian Fire Chief, which is now headed by Jakarta Fire Chief.

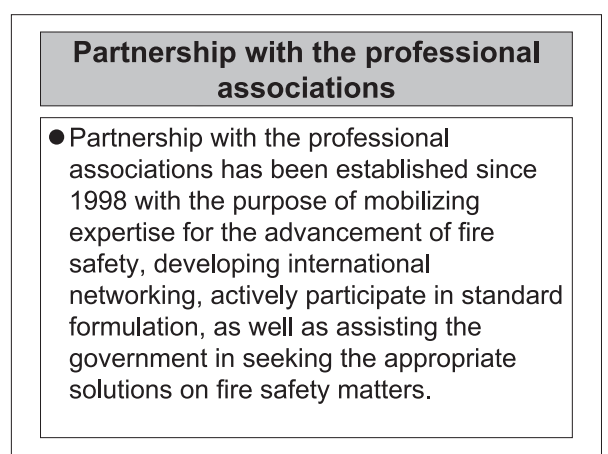

Figure 2-5-26

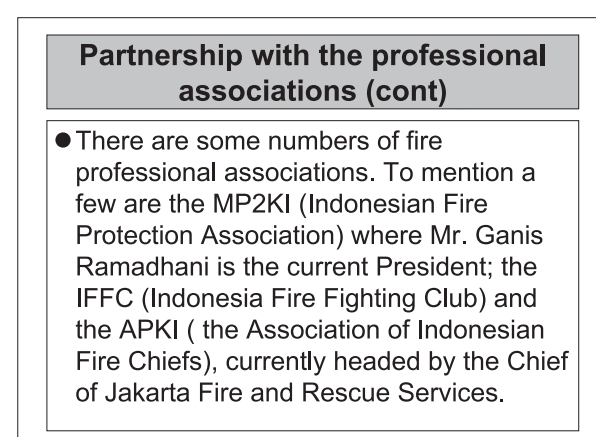

Figure 2-5-27 
This is the one of the main vision (Figure 2-5-28) to become the world class national body in organizing and mobilizing fire protection professional to actively perform as the source of information, reference, and solutions in the effort of life safety and loss prevention against fire for all stakeholders.

The mission, and beside that we also try to empowering community by making what we call SKKL and following the fire brigade.

(Figure 2-5-29) and (Figure 2-5-30)

\begin{tabular}{|l|}
\hline Indonesia Fire Protection Association (MP2KI) \\
\hline Mission: \\
1.Through promoting networking amongst fire \\
experts, related institutions, industries, association, \\
MP2KI intends to be an information source and \\
provide solutions on various fire protection \\
problems; \\
2.To develop and enhance the profession of fire \\
safety and protection, to achieve higher recognition \\
which will in turn, increase life safety measures, as \\
well as intensifying the capacity of fire prevention, \\
control and suppression of fires.
\end{tabular}

Figure 2-5-29
Indonesia Fire Protection Association (IFPA)

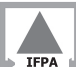

\section{Vision :}

To become the world class national body in organizing and mobilizing fire protection professionals to actively perform as the source of information, references and solutions in the effort of life safety and loss prevention against fire for all stakeholders

Figure 2-5-28

\section{Community participation}

People participation is needed, especially in densely populated urban areas, where fire may involved many houses (big fires).

- For this reason, the settlement environs fire protection system (SKKL) was established with the purpose of increasing people awareness and training people to use fire extinguishers, etc.

- Some persons are appointed to be fire volunteers (BALAKAR) through special training on fire fighting, completed with uniform and certificated.

Figure 2-5-30

Now, we have fire test laboratory. (Figure 2-5-31) It was built in 1991 under cooperation with MOC, now perhaps NILIM. At that time MOC where Dr. Suzuki has already been 5 years there. He was our tutor, with housing laboratory equipment mostly for testing material, properties, and fire resistance of structural component.

Equipment we have combustibility, ignitability, flammability, we have also a newly installed cone calorimeter. (Figure 2-5-32) The equipment of fire resistance included a small vertical furnace and multi-use furnace.

\section{FIRE TEST LABORATORY}

- Fire test laboratory in Cileunyi, Bandung, was built in $90 / 91$. This lab $\left(1000 \mathrm{~m}^{2}\right)$ within 9,8 hectares of RIHS premise, was built under the cooperation between MOC, Japan and MPW, Indonesia which housing labora-tory equipment mostly for testing of building material properties and fire resistance of structural components.

\section{FIRE TEST LABORATORY (CONT)}

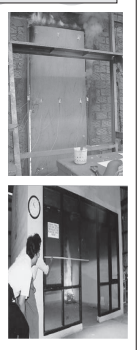

- Equipment for material fire properties are non combustibilty tester, ignitability tester, surface tester, flammability tester, fire propagation tester, flame cabinet, conductivity meter, gas analyzer, and a newly installed cone calorimeter

- The equipment for fire resistance test include a small scale vertical furnace $(1.05 \mathrm{x}$ $1.07 \mathrm{~m})$, a vertical fire furnace, and a multiuse furnace. 
There is some research conducted, thermal properties, insulating, survey on building damage, research on big fires, evaluation of Bali beach after fire accident, role of building canopy and so on. (Figure 2-5-33)

Now, education. (Figure 2-5-34) This is quite specific. Until 1990s universities in Indonesia are not quite interested in promoting fire safety or fire protection engineering as

\section{Some research conducted}

- Thermal properties of building materials and fire resistance of structural components

- Fire properties of insulating materials

- Survey on building damages cause by fires

- Research on big fires and the effects of people participation

- Evaluation of Bali Beach Hotel after fire incidents

- Study on the establishment of national fire incidents data

- Role of building canopy to prevent vertical fire propagation

- Reseach on the cost of fire protection in buildings

- Study on the environment friendly fire protection systems

- Application of fire safety management in public buildings

Figure 2-5-33 an academic subject of learning as other conventional subjects such as mechanical, chemical. But fire protection as subject of professional has been taught firstly in University of Indonesia.

In 2003, fire protection has been included as an optional subject in the master degree program in ITB in engineering physics department and in architectural department. (Figure 2-5-35)

\section{Fire safety education}

Up to 1990's, universities in Indonesia are not quite interested in promoting fire safety or fire protection engineering as an academic subject of learning as other conventional subjects such as mechanical, electrical or chemical engineering. But a fire protection as a subject of professional engineering courses has been taught inUniversity of Indonesia.

Figure 2-5-34

\section{Fire safety education (continued)}

- In 2003, fire protection has been included as an optional subject in the master degree academic program for building physics department, in the Engineering Physics Department, of the Institute of Technology Bandung (ITB) and noted as one of the reseach topics of thesis for students persuing master degree in the Architecture Department of ITB.

Figure 2-5-35

In 2010 (Figure 2-5-36) a new program study of fire protection within mechanical engineering was set up in University of Jakarta, UNJ, which also opened for fire service professional and recently in 2011 an architectural student from ITB has finished her doctor program with the dissertation focusing on hospital fire escape simulation.

You see that I am alone in Indonesia because

\section{Fire safety education (continued)}

- Starting 2010, a new program study for fire protection within mechanical engineering department has been opened for undergraduate students of the University of Jakarta (UNJ), Jakarta, which open also for fire service personnels. And recently, in November 2011, an Architecture student of ITB (Ms. Lily Tambunan) has finished her doctor degree program, with the dissertation focusing on hospital fire escape simulation.

Figure 2-5-36 not so many people are interested in fire. But having in this forum I feel I am not alone anymore. We have you. 
This is proposed educational research. (Figure 2-5-37) Perhaps we can propose model of public education on fire and research mitigation. University partnership if any in fire education and research is we are interested in risk based fire safety management, fire coat, and harmonization of Asia, fire protection in densely populated urban areas and fire protection in heritage building.

What are expected from this forum? (Figure 2-5-38) We expect to arrange periodic seminar forum on fire safety on the specific thing, to publish Asian journal on fire safety, to promote networking among fire education researcher. The picture on the right side is fire following earthquake in Nias.

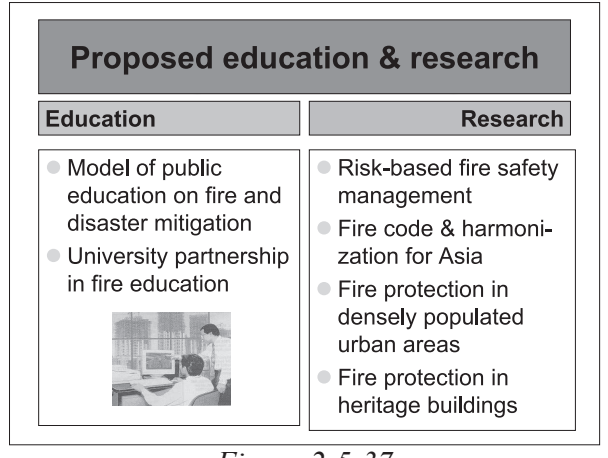

Figure 2-5-37

\section{What are expected from the Forum ?}

- To arrange periodic seminar forum on fire safety under specific theme

- To publish Asian Journal on Fire Safety

- To promote networking among fire educator / researcher

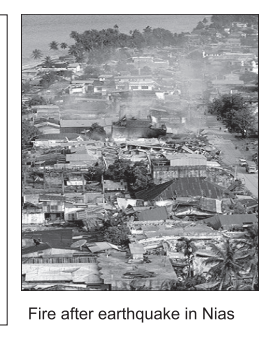

Figure 2-5-38

Thank you very much. (Figure 2-5-39)

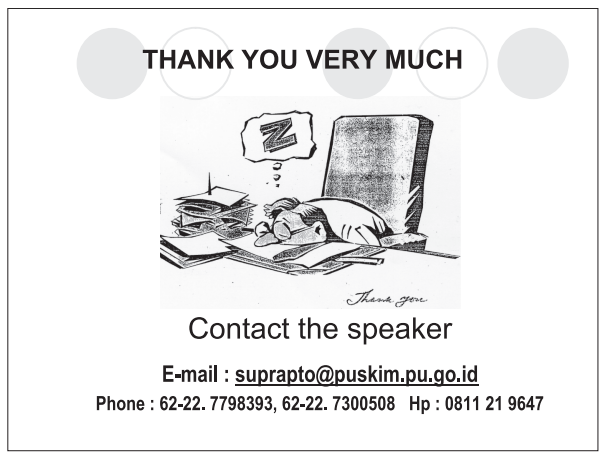

Figure 2-5-39 